\title{
Dual-degradable disulfide-containing PEI-Pluronic/ DNA polyplexes: transfection efficiency and balancing protection and DNA release
}

This article was published in the following Dove Press journal:

International Journal of Nanomedicine

27 September 2013

Number of times this article has been viewed

\section{Lifen Zhang* \\ Zhenzhen Chen* \\ Yanfeng Li}

State Key Laboratory of Applied Organic Chemistry, Key Laboratory of Nonferrous Metals Chemistry and Resources Utilization of Gansu Province, College of Chemistry and Chemical Engineering, Institute of Biochemical Engineering and Environmental Technology, Lanzhou University, Lanzhou, People's Republic of China

*These authors contributed equally to this work
Correspondence: Lifen Zhang; Yanfeng Li College of Chemistry and Chemical Engineering, Institute of Biochemical Engineering and Environmental

Technology, Lanzhou University, Lanzhou 730000, People's Republic of China Email Ifzhang@|zu.edu.cn; liyf@lzu.edu.cn

\begin{abstract}
Polymeric gene-delivery vectors to achieve lack of toxicity and a balance between protection and DNA release remains a formidable challenge. Incorporating intracellular environment-responsive degradable bonds is an appreciable step toward developing safer transfection agents. In this study, novel, dual-degradable polycation copolymers (Pluronic-diacrylate [PA]-polyethyleneimine [PEI]-SS) were synthesized through the addition of low molecular weight (800 Da) PEI cross-linked with SS (PEI-SS) to PA. Three PA-PEI-SS copolymers (PA-PEI-SS1, 2, and 3) with different PEI-SS to Pluronic molar ratios were investigated and found to strongly condense plasmid DNA into positively charged nanoparticles with an average particle size of approximately $200 \mathrm{~nm}$ and to possess higher stability against DNase I digestion and sodium heparin. Disulfide and ester bonds of the copolymers were susceptible to intracellular redox conditions. In vitro experiments demonstrated that the PA-PEI-SS copolymers had significantly lower cytotoxicity and higher transfection efficiency in both BGC-823 and 293T cell lines than the controls of degradable PEI-SS and nondegradable $25 \mathrm{kDa}$ PEI. Transfection activity was influenced by the PEI-SS content in the polymers and PA-PEI-SS1 showed the highest efficiency of the three copolymers. These studies suggest that these dual-degradable copolymers could be used as potential biocompatible gene delivery carriers.
\end{abstract}

Keywords: Pluronic, PEI, gene vector, dual-degradable, disulfide-containing linker

\section{Introduction}

Gene therapy has the potential to treat a wide variety of inherited and acquired genetic disorders, such as diabetes, cystic fibrosis, cancer, and hemophilia. ${ }^{1-3}$ Nonviral vectors, composed of cationic polymers, lipids, and peptides able to form ionic complexes with DNA are safer, cheaper, have lower immunogenicity, and are easier to produce in comparison with viral vectors. Unfortunately, these nonviral gene delivery systems are also much less efficient in terms of transgene expression levels. ${ }^{4}$ This low efficacy is caused by many barriers throughout the gene delivery pathway, ${ }^{5-7}$ including cellular localization and binding, internalization, subcellular trafficking, endosomal escape, unpacking and release, and nuclear translocation. A major challenge is how to engineer the competing functionalities of protection and efficient DNA release into polymeric gene carriers. The key considerations in the rational design of safe and efficient new gene delivery systems are lack of toxicity and achieving a balance between protection and DNA release.

Polyethyleneimine (PEI) has been regarded as a potential candidate for use in nonviral gene vectors, as it has considerable transfection efficiency ${ }^{8,9}$ due to the so-called intrinsic "proton sponge" effect. ${ }^{10,11}$ PEI has, however, been poorly 
represented in clinical trials, mainly due to its poor in vivo transfection activity and acute cytotoxicity. ${ }^{12-14}$ Unfortunately, transfection efficiency and cytotoxicity appear to be related; PEI with low molecular weight $($ LMW) (ie, molecular weight $=800 \mathrm{Da}, 2,000 \mathrm{Da}$, or less) exhibits lower cytotoxicity and lower transfection efficiency, whereas PEI with high molecular weight (ie, $25 \mathrm{kDa}$ ) exhibits higher transfection efficiency but also higher cytotoxicity. ${ }^{15,16}$

Currently, efforts are being undertaken to decrease cytotoxicity and improve the transfection efficiency of gene vectors by cross-linking LMW units via linkages that are potentially degradable. ${ }^{5,17,18}$ A degradable LMW-based PEI cross-linked with reversible disulfide bonds exhibited higher transfection efficiency but less toxicity in cell cultures than the standard $25 \mathrm{kDa}$ PEI. ${ }^{19,20}$ Disulfide bridges in the polymer backbones, or the cross-linkages of polymers, have been shown to be stable in blood circulation, but degradation occurs rapidly (from within minutes to hours) in the presence of reductive glutathione. These reductive conditions mimic the reductive intracellular environment in the cytosol. Ester- and/or amide-based derivatives have been obtained by cross-linking LMW PEI with either ethylene glycol bis(succinimidylsuccinate), disuccinimidyl suberate, ${ }^{21}$ or small diacrylate linkers. ${ }^{22} \mathrm{Wu}$ et al found that degradable polycations formed by the addition of diamines to diacrylates displayed 4- to 8-fold higher gene transfer activity than $25 \mathrm{kDa}$ PEI. ${ }^{22}$ Further studies reported the synthesis and screening of degradable poly(amino esters) generated by Michael addition of amines to a variety of diacrylates. $^{23-25}$

Hydrophilic Pluronic polymers (poly[ethylene oxide]b-poly[propylene oxide]-b-poly[ethylene oxide]) have been extensively used to enhance the efficiency of transfection of some cationic polymers and viral vectors in vitro and in vivo due to their excellent biocompatibility and environmental sensitivity. ${ }^{26,27}$ The biocompatibility of the cationic polymer might be improved by grafting with Pluronic copolymers in a similar fashion to that observed with polyethylene glycol (PEG)-ylation. ${ }^{28}$ Guo et $\mathrm{al}^{29}$ reported that Pluronic-grafted PEI displayed higher transfection activity with lower cytotoxicity than $25 \mathrm{kDa}$ PEI, owing to the ability of the Pluronic copolymer to adhere to the cell membrane. Interestingly, addition of Pluronic P123 or P85 to the PEI-based polyplexes significantly enhanced pDNA (plasmid DNA) cellular uptake, nuclear translocation, and gene expression in several cell lines as a result of the binding of Pluronic with the cellular membrane and activation of cell-signaling pathways. ${ }^{30,31}$
Few references so far have proposed that the conjugation of Pluronic with PEI-SS (disulfide-containing PEI) via ester hydrolysis bonds may achieve efficient transfection and a balance between protection and efficient DNA release.

In this work, we attempted to design and synthesize a lower cytotoxic, highly efficient, dual-degradable nonviral carrier formed by the conjugation of disulfide-containing PEI-SS with Pluronic-diacrylate (PA) via Michael addition. Introduction of Pluronic into bioreducible LMW PEI-SS systems via degradable ester bonds should result in a complex that is not only stable in the extracellular matrix, but also able to be cleaved intracellularly to release the entrapped DNA, resulting in low cytotoxicity and a good balance between protection and DNA release, as shown in Figure 1. Characterizations of the stability of polyplexes in physiological conditions, sensitivity to reducing environment, and transfection ability of the polyplexes were tested. The PA-PEI-SS complexes revealed strong DNA condensation and higher stability against DNase I digestion and sodium heparin. Moreover, the PA-PEI-SS copolymers had significantly lower cytotoxicity and higher transfection efficiency in both BGC-823 and 293T cell lines than the controls of degradable PEI-SS and nondegradable $25 \mathrm{kDa}$ PEI.

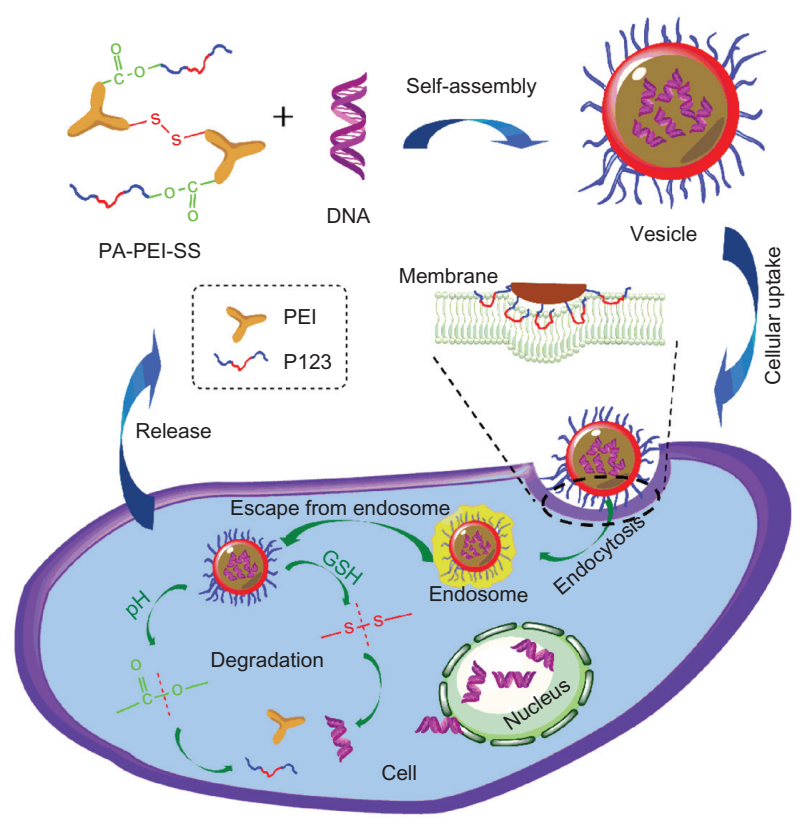

Figure I Preparation of the dual-degradable PA-PEI-SS for efficient intracellular delivery and release of DNA.

Note: The copolymer can be degraded to more small molecules by cleaving the covalent bonds when the $\mathrm{pH}$ becomes lower than 7.4. Generally, the $\mathrm{pH}$ value in the cytoplasm is lower than 7.4.

Abbreviations: GSH, glutathione; PA, Pluronic-diacrylate; PEI, polyethyleneimine; SS, disulfide. 


\section{Materials and methods Materials}

Linear PEI $\left(M_{w}\right.$ [weight-average molecular weight $]=800$ Da), branched PEI $\left(M_{w}=25 \mathrm{kDa}\right)$, cystamine dihydrochloride, dithiothreitol (DTT), Pluronic P123, dimethyl sulfoxide (DMSO), 1,1-carbonyldiimidazole, 3-(4,5-dimethylthiazol-2-yl)-2,5-diphenyltetrazolium bromide (MTT), Dulbecco's Modified Eagle's Medium (DMEM), and Dulbecco's phosphate-buffered saline (PBS) were purchased from Sigma-Aldrich (St Louis, MO, USA) and used without further purification. Acryloyl chloride (analytical grade) was purchased from Rionlon Bohua (Tianjin) Pharmaceutical and Chemical Co, Ltd (Tinajin, People's Republic of China) and used as received. Fetal bovine serum (FBS) and penicillin-streptomycin solution were purchased from Life Technologies (Carlsbad, CA, USA). $293 \mathrm{~T}$ and BGC-823 cells were kindly donated by Professor Fang (Lanzhou University, Lanzhou, People's Republic of China). Plasmid pBR322 DNA was purchased from Fermentas China Co, Ltd, plasmid enhanced green fluorescent protein ( $\mathrm{pEGFP}$ ) containing the early promoter of Cytomegalovirus and enhanced green fluorescent protein (EGFP) were kindly donated by Professor Liang (Jianghan University, Wuhan, People's Republic of China).

\section{Methods}

\section{Synthesis of PEI-SS}

Cystamine bisacrylamide (CBA) was synthesized from acryloyl chloride and cystamine (1:1) with catalytic triethylamine in dichloromethane at room temperature, according to conventional Schotten-Baumann conditions. The crude product was obtained by filtration, washed twice with distilled water, and further purified by crystallization from ethyl acetate and dried under vacuum. The structure was confirmed by hydrogen-1 nuclear magnetic resonance ( ${ }^{1} \mathrm{H}$ NMR), as described in a previous study. ${ }^{6}$

Reducible PEI-SS was synthesized by Michael addition of CBA to branched $800 \mathrm{Da}$ PEI at a ratio of 1:2. Briefly, PEI $(1 \mathrm{mmol})$ was dissolved in $10 \%$ aqueous methanol $(10 \mathrm{~mL})$ and added to a three-necked flask equipped with a condenser at $45^{\circ} \mathrm{C}$ under nitrogen. $\mathrm{CBA}(0.5 \mathrm{mmol})$ was dissolved in methanol $(6 \mathrm{~mL})$ and added drop-wise to the PEI solution. The reaction mixture was stirred in the dark under nitrogen at $45^{\circ} \mathrm{C}$ for $\geq 24$ hours. Subsequently, $10 \%$ excess PEI in methanol $(2 \mathrm{~mL})$ was added to consume any unreacted CBA and the mixture stirred for another 6 hours. The reaction mixtures were acidified to $\mathrm{pH} 4$ with $1.0 \mathrm{M}$ hydrogen chloride solution and dialyzed with distilled water $\left(M_{w}\right.$ cutoff $\left.=3,500 \mathrm{Da}\right)$. The final products were obtained after lyophilization. The apparent molecular weight of the copolymers was determined by gel permeation chromatography-multi-angle laser light scattering (GPC-MALLS). Functionalization was confirmed using ${ }^{1} \mathrm{H}$ NMR.

\section{Synthesis of PI23-diacrylate (PI23-DA)}

Diacrylate-terminated $\mathrm{P} 123$ was synthesized by reacting diol-terminated P123 with an excess of acryloyl chloride and catalytic triethylamine in anhydrous dichloromethane at room temperature. Briefly, P123 (25 g) was dissolved in anhydrous dichloromethane $(200 \mathrm{~mL})$ and added to a three-necked flask. The solution was cooled to between $0^{\circ} \mathrm{C}$ and $5^{\circ} \mathrm{C}$, and triethylamine $(25 \mathrm{~mL})$ and acryloyl chloride $(8 \mathrm{~mL})$ were added simultaneously with stirring. The mixture was placed in an ice bath for 6 hours, then kept at room temperature for another 24 hours. P123-DA was purified by filtration, liquid-liquid extraction in dichloromethane, precipitation from diethyl ether, and dialyzation with distilled water $\left(M_{w}\right.$ cutoff $\left.=7,000 \mathrm{Da}\right)$ for 3 days then lyophilized for 2 days. The structure of P123-DA was analyzed by ${ }^{1} \mathrm{H}$ NMR.

\section{Synthesis of PA-PEI-SS}

A series of multi-block PA-PEI-SS copolymers was synthesized by conjugating P123-DA to PEI-SS (Figure 2). In a typical polymerization procedure, PEI-SS $(0.176,0.088$, and $0.044 \mathrm{mmol})$ and P123-DA $(0.088 \mathrm{mmol})$ were dissolved in methanol $(3 \mathrm{~mL})$ in separate vials. Then, the P123-DA solutions were added to each PEI-SS solution with stirring. The reaction was performed at $45^{\circ} \mathrm{C}$ for 48 hours with shaking. After cooling to room temperature, the obtained copolymers (PA-PEI-SS1, PA-PEI-SS2, and PA-PEI-SS3) were dialyzed with distilled water $\left(M_{w}\right.$ cutoff $\left.=14,000 \mathrm{Da}\right)$ for 3 days and lyophilized for 2 days. The molar ratio of PEI-SS to P123 in the PA-PEI-SS copolymers was calculated from the ${ }^{1} \mathrm{H}$ NMR data. The apparent molecular weight of the copolymers was determined by GPC-MALLS.

\section{Characterization of the synthesized polymers}

${ }^{1} \mathrm{H}$ NMR spectra were recorded on a Varian Mercury VX-300 MHz spectrometer (Palo Alto, CA, USA). GPC-MALLS analysis was carried out on a DAWN ${ }^{\circledR}$ DSP multi-angle laser photometer with a P100 pump (Thermo Seperation Products, San Jose, CA, USA) equipped with TSK-GEL G6000 PWXL with a G4000 PWXL column $(7.8 \times 300 \mathrm{~mm})$ and a differential refractive index detector 

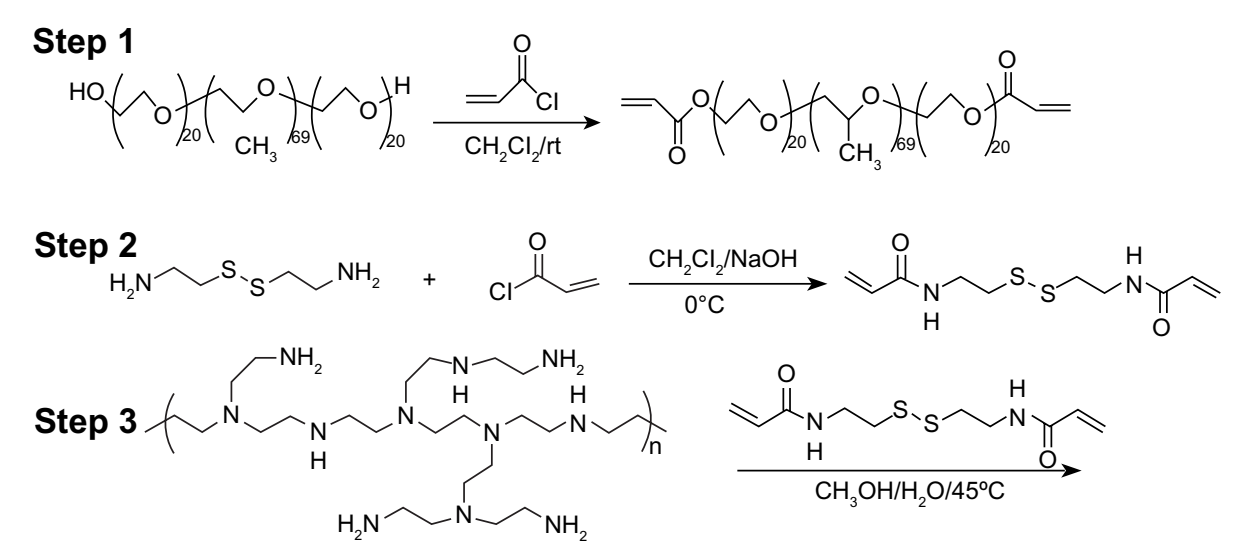<smiles>CCN(CCNCCC(C)(C)C)CCN(CCNCCN)CCNCCN(CCN)CC(C)(C)C</smiles>

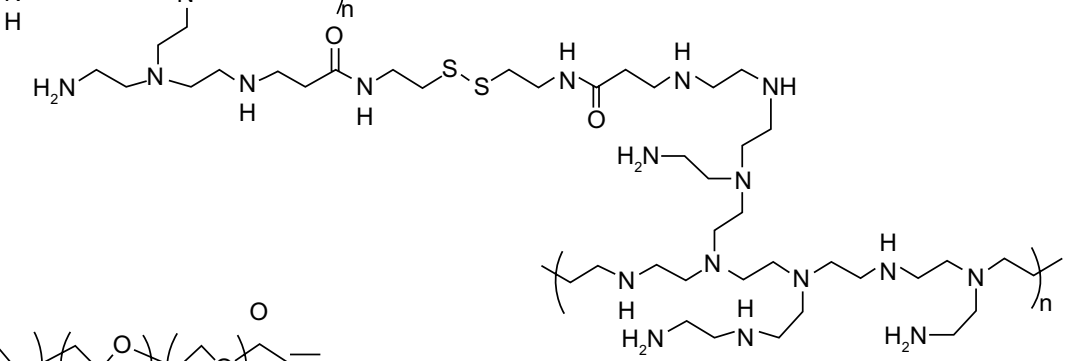

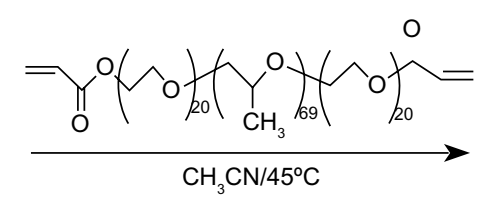

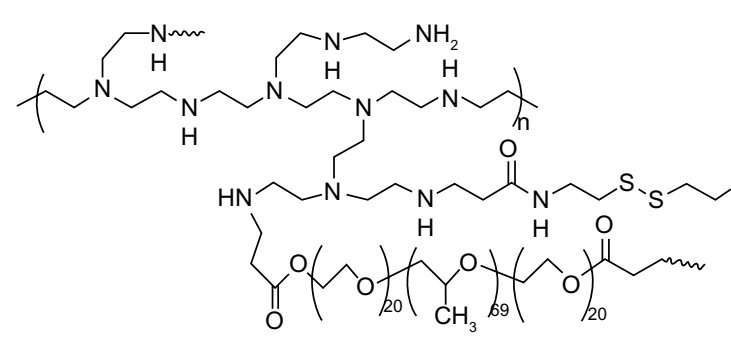<smiles>CCCNC(=O)CCNCCNCCN(CC)CCN</smiles><smiles>CNCCNCCN(CCNCCNCC(C)(C)C)CCNCCN(CCN)CCN(CCN)CC(C)(C)C</smiles>

Figure 2 Synthesis of PA-PEI-SS.

Abbreviations: PA, Pluronic-diacrylate; PEI, polyethyleneimine; SS, disulfide; rt, room temperature.

(RI-150, Japan) at $25^{\circ} \mathrm{C}$. The flow rate of the mobile phase with water was kept at $1 \mathrm{~mL} / \mathrm{min}$.

\section{Dual degradation of the copolymers}

Copolymer degradation was estimated by measurement of the molecular weights of the copolymers by GPC-MALLS. The PA-PEI-SS1 copolymer was dissolved in acetate buffer (0.2 M, pH 5.1) or PBS (0.2 M, pH 7.4), with or without DTT, at a concentration of $5 \mathrm{mg} / \mathrm{mL}$. Samples were incubated at $37^{\circ} \mathrm{C}$ on a mechanical rotator with shaking at $100 \mathrm{rpm}$, and aliquots $(1 \mathrm{~mL})$ were removed at appropriate time intervals.
Aliquots were frozen immediately in liquid nitrogen and lyophilized. The molecular weights of lyophilized samples were measured by GPC-MALLS.

\section{Preparation of copolymer/DNA complexes}

All copolymer/DNA complexes diluted in PBS were incubated at room temperature for 30 minutes for complex formation before use. The copolymer/DNA charge (N/P) ratio was expressed as the molar ratio of the amine groups of the copolymer to phosphate groups of the DNA. The N/P ratio was $7.75 \mathrm{PEI} / \mathrm{DNA}$. Complexes were prepared by adding 
copolymer solutions to equal volumes of either pBR322 plasmid $(0.5 \mu \mathrm{g})$ or pEGFP $(1 \mu \mathrm{g})$, with gentle vortexing. Complexes were formed in PBS at pH 7.4.

\section{Agarose gel electrophoresis assay}

Appropriate amounts of copolymer were added to $4 \mu \mathrm{g}$ of DNA solution to achieve the desired ratio of polymer to DNA. The complexes were incubated for 30 minutes, and $20 \mu \mathrm{L}$ of a $0.1 \mathrm{mg} / \mathrm{mL}$ ethidium bromide solution were added and solutions were mixed by pipetting, after which $10 \mu \mathrm{L}$ was loaded into a $0.8 \%$ agarose gel with ethidium bromide $(400 \mathrm{ng} / \mathrm{mL})$ and run with Tris acetate buffer $(\mathrm{pH} 8)$ at 80 $\mathrm{V}$ for 80 minutes. DNA retardation was visualized by an ultraviolet $(254 \mathrm{~nm})$ illuminator and photographed with a gel imaging system (ImageQuant 400, France).

\section{Resistance to DNase I digestion and sodium heparin}

To evaluate the protection of DNA by copolymers, $2 \mu \mathrm{L}$ of DNase I ( $5 \mathrm{U} / \mu \mathrm{L})$ was used to digest $0.5 \mu \mathrm{g}$ of DNA formulated with PA-PEI-SS copolymers at $37^{\circ} \mathrm{C}$ for 1 hour. After digestion, $5 \mu \mathrm{L}$ of $2 \%$ SDS (sodium dodecyl sulfate) was added to dissociate DNA from the complexes, or $5 \mu \mathrm{L}$ of different concentrations of sodium heparin solution were then added to resistance capacities of PA-PEI-SS copolymers. The mixed solution was incubated at $37^{\circ} \mathrm{C}$ for 1 hour. After that, the resistance capacities of PA-PEI-SS/DNA to DNase I digestion and sodium heparin were evaluated by electrophoresis. ${ }^{32,33}$ Images were recorded with the ImageQuant 400 system.

\section{Particle size and zeta potential}

The size and surface charge of the copolymer/DNA complexes were measured at room temperature using a ZetaPlus zeta potential analyzer (Brookhaven Instrument Co, Holtsville, NY, USA) equipped with a $15 \mathrm{mV}$ solidstate laser operated at a wavelength of $635 \mathrm{~nm}$ and an angle of $90^{\circ}$.

\section{Transmission electron microscopy (TEM)}

The polyplexes were first prepared in an Eppendorf tube, according to the above method for preparation of complexes with different N/P ratios, then a drop of the polyplex solution was placed on a Formvar precoated carbon grid for 30 minutes and the excess sample blotted away with filter paper. Samples were stained with $1 \%$ phosphotungstic acid for 15 minutes and the excess phosphotungstic acid was blotted away with filter paper. The samples were analyzed using a JEM-1230 TEM microscope (JEOL, Tokyo, Japan) at $100 \mathrm{kV}$.

\section{Cell culture}

Human embryonic kidney transformed 293 (293T) and human gastric carcinoma cell line (BGC-823) cells were incubated in DMEM with $10 \%$ FBS and $1 \%$ antibiotic solution (penicillin-streptomycin, $10,000 \mathrm{U} / \mathrm{mL}$ ) at $37^{\circ} \mathrm{C}$ in a humidified atmosphere containing $5 \% \mathrm{CO}_{2}$.

\section{Cytotoxicity assay}

The cytotoxicity of the different polymers was investigated using the MTT assay for both 293T and BGC-823 cells. Briefly, the cells were seeded in a 96-well plate at a density of 7,000 cells/well, then cells were incubated in DMEM $(100 \mathrm{~mL})$ containing 10\% FBS under a humidified atmosphere of $95 \%$ air and $5 \% \mathrm{CO}_{2}$ for 24 hours. Thereafter, the medium was replaced with fresh medium $(90 \mu \mathrm{L})$, and solutions of $25 \mathrm{kDa}$ PEI, PEI-SS, and PA-PEI-SS copolymers $(10 \mu \mathrm{L})$ were added. Each dosage was replicated in three wells. Forty-eight hours after the polymers were added, MTT solutions $(5 \mathrm{mg} / \mathrm{mL}, 10 \mu \mathrm{L})$ were added to each well, which were incubated for a further 4 hours. Then, the medium was removed and DMSO $(100 \mathrm{~mL})$ was added. The absorbance was measured at $570 \mathrm{~nm}$ using a microplate reader (model 550; Bio-Rad Laboratories, Hercules, CA, USA). The relative cell viability was calculated as:

$$
\begin{aligned}
\text { Viability }(\%)= & \left(\mathrm{OD}_{\text {sample }}-\mathrm{OD}_{\text {blank }}\right) / \\
& \left(\mathrm{OD}_{\text {control }}-\mathrm{OD}_{\text {blank }}\right) \times 100,
\end{aligned}
$$

where $\mathrm{OD}_{\text {sample }}$ is the absorbance of the solution of the cells cultured with the polymer or PEI, $\mathrm{OD}_{\text {blank }}$ is the absorbance of the medium, and $\mathrm{OD}_{\text {control }}$ is the absorbance of the solution of the cells cultured with the medium only.

\section{In vitro transfection activity of polyplexes \\ Green fluorescent protein assay}

For transfection experiments, pEGFP was used to evaluate the transfection efficiency of PA-PEI-SS copolymers; PEI-SS and $25 \mathrm{kDa}$ PEI were used as positive controls. The 293T and BGC823 cells were seeded in a 24 -well plate at a density of $5 \times 10^{4}$ cells/well. The cells were incubated at $37^{\circ} \mathrm{C}$ for 24 hours in a humidified atmosphere of $95 \%$ air and $5 \% \mathrm{CO}_{2}$. The medium in each well was replaced with DMEM $(1 \mathrm{~mL})$ without FBS. PA-PEI-SS/DNA complexes were added at various N/P ratios from 10 to 40 and incubated with cells for 4 hours at $37^{\circ} \mathrm{C}$. PEI$\mathrm{SS}$ and $25 \mathrm{kDa}$ PEI were used as controls. The amount of DNA added to each well was $1 \mu \mathrm{g}$. The medium was replaced with $1 \mathrm{~mL}$ of fresh DMEM medium with $10 \% \mathrm{FBS}$, and the cells were further incubated for 48 hours. EGFP transfections were 
studied using an inverted fluorescence microscope (DMI 4000 B; Leica Microsystems, Wetzlar, Germany). The microscopy images were obtained at a magnification of $100 \times$.

\section{Flow cytometry}

After the transfection, cells were separately harvested from each well by treatment with trypsin-ethylenediaminetetraaceti c acid and suspended in PBS (1 mL) in microcentrifuge tubes. The cells expressing green fluorescent protein were enumerated by fluorescence-activated cell sorting (FACSCanto ${ }^{\text {TM}}$; BD Biosciences, San Jose, CA, USA). The non-transfected cells were used as a negative control.

\section{Results and discussion Synthesis and characterization of PA-PEI-SS}

The chemical structure, synthesis, and characteristics of the copolymer PA-PEI-SS are shown in Figures 2 and 3, and Table 1. Cross-linking of low-toxicity branched $800 \mathrm{Da}$
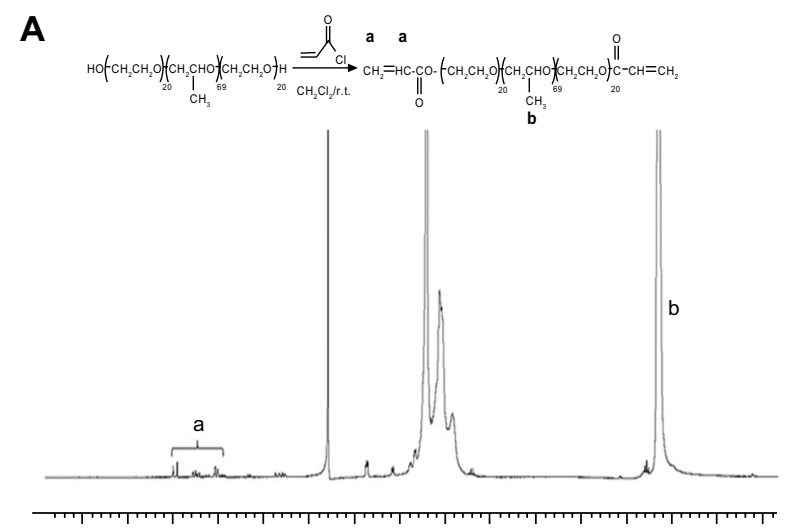

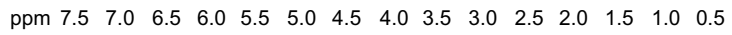

\section{B}

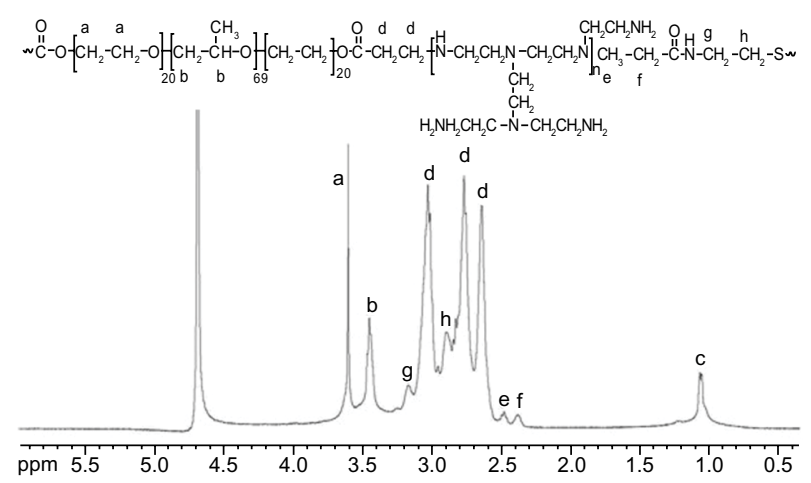

Figure 3 'H NMR spectra of PI23-diacrylate (A) and PA-PEI-SS (B).

Note: Lowercase letters (a-h) shown above peaks indicate different proton chemical shifts.

Abbreviations: 'H NMR, hydrogen-I nuclear magnetic resonance; PA, Pluronicdiacrylate; PEI, polyethyleneimine; Ppm, parts per million; SS, disulfide.
Table I Characteristics of PEI-SS and PA-PEI-SS copolymers

\begin{tabular}{|c|c|c|c|c|c|c|}
\hline \multirow[t]{2}{*}{ Sample } & \multicolumn{2}{|c|}{ Molar ratio } & \multirow[t]{2}{*}{ Yield (\%) } & \multirow[t]{2}{*}{$M_{w}{ }^{c}$} & \multirow[t]{2}{*}{$M_{n}^{c}$} & \multirow[t]{2}{*}{ PDI $^{\circ}$} \\
\hline & $\begin{array}{l}\text { Feed } \\
\text { ratio }^{\mathrm{a}}\end{array}$ & $\begin{array}{l}\text { Actual } \\
\text { ratio }^{b}\end{array}$ & & & & \\
\hline PEI-SS & I & I & 64 & 21,500 & 15,050 & 1.4 \\
\hline PA-PEI-SSI & 2.0 & 1.8 & 62 & 43,420 & 22,852 & 1.9 \\
\hline PA-PEI-SS2 & 1.0 & 0.8 & 59 & 64,380 & 58,527 & 1.1 \\
\hline PA-PEI-SS3 & 0.5 & 0.4 & 45 & 33,350 & 22,233 & 1.5 \\
\hline
\end{tabular}

Notes: a Molar ratio of PEI-SS to Pluronic used in the copolymerization reaction; bmolar ratio of PEI-SS to Pluronic in the copolymers as determined by 'H NMR spectra; 'copolymer molecular weight and PDI were determined by GPC-MALLS.

Abbreviations: 'H NMR, hydrogen-I nuclear magnetic resonance; GPC-MALLS, gel permeation chromatography-multi-angle laser light scattering; PA, Pluronicdiacrylate; PDI, polydispersity index; PEI, polyethyleneimine; SS, disulfide; $M_{w}$, weight-average molecular weight; $M_{n}$, number-average molecular weight.

PEI using degradable linkages was conceived as a way of increasing molecular weight and thus enhancing DNAbinding capacity and polyplex stability while maintaining the nontoxic nature. PEI-SS was successfully prepared by the conjugation of $\mathrm{PEI}$ and $\mathrm{CBA}$ at a ratio of $2: 1$; at this ratio, the density of disulfide linkages in the PEI-SS was higher than that of other ratios and the resulting complex was found to be more efficient at transfection. ${ }^{20}$ The structure was confirmed by ${ }^{1} \mathrm{H}$ NMR (data not shown).

Both terminal hydroxyl groups of Pluronic P123 were diacrylated using acryloyl chloride in order to perform the coupling reaction with the primary amino groups present in PEI-SS. The structure of P123-DA was confirmed by ${ }^{1} \mathrm{H}$ NMR (Figure 3A). The characteristic proton peaks of the double bonds of acryloyl chloride at 5.5-6.5 ppm indicated the activation of the Pluronic copolymer. Figure 3B shows the ${ }^{1} \mathrm{H}$ NMR spectra of PA-PEI-SS in $\mathrm{D}_{2} \mathrm{O} .-\mathrm{CH}_{2} \mathrm{CH}_{2} \mathrm{O}$ - proton peaks appear at $\delta=3.55 \mathrm{ppm}$ and $-\mathrm{CH}_{2} \mathrm{CH}_{2}-\mathrm{NH}-$ proton peaks appear at $\delta=2.51-2.7 \mathrm{ppm}$, indicating that $\mathrm{P} 123$ has been coupled to PEI-SS successfully.

Three different molar ratios of PEI-SS to Pluronic (PAPEI-SS1, PA-PEI-SS2, and PA-PEI-SS3) were tested to optimize the copolymerization conditions. The molecular weights and polydispersity index for PA-PEI-SS1, PA-PEISS2, and PA-PEI-SS3 are listed in Table 1. It was observed that different feed molar ratios resulted in copolymers with different molecular weights.

\section{Characterization of copolymer/DNA complexes}

To be effective at gene delivery, one prerequisite for a polymeric gene carrier is to be capable of DNA condensation in a format that can be easily taken up by cells. In addition, PA-PEI-SS copolymer degradation must not weaken the complex, thereby exposing the condensed DNA to cellular 
A Sodium heparin
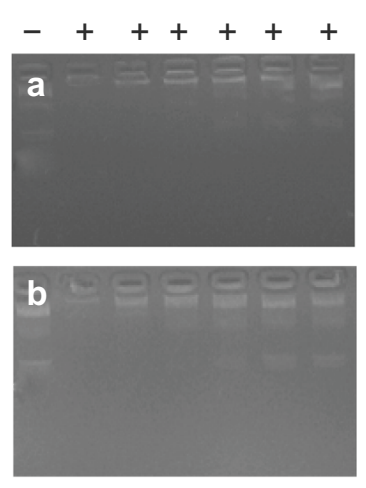

C
B N/P $\begin{array}{llllllllllll}0 & 1 & 2 & 3 & 5 & 7 & 0 & 1 & 3 & 7 & 10 & 15\end{array}$

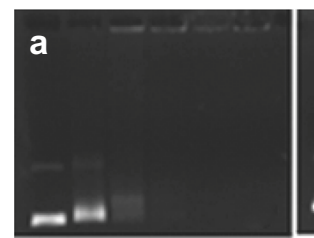

C Free DNA

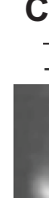

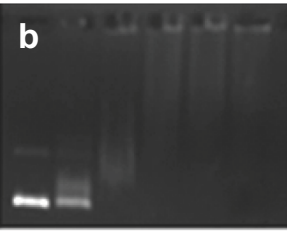

(a)

(b)

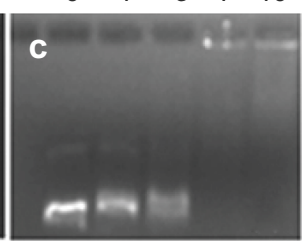

(c)

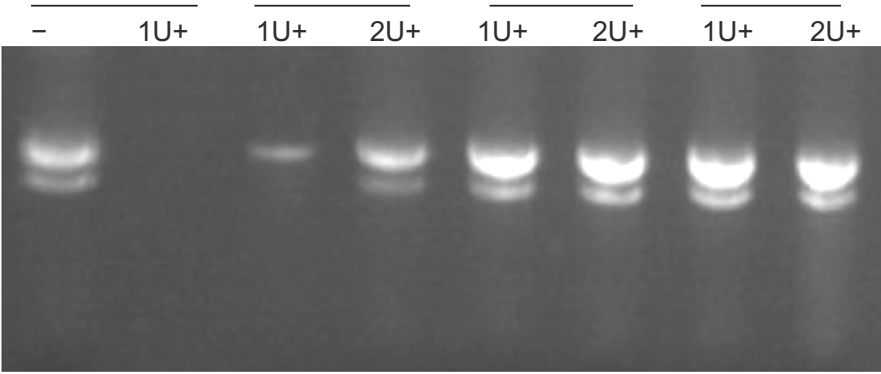

Figure 4 Agarose gel electrophoresis analysis.

Notes: The used plasmid DNA in each sample was $0.8 \mu \mathrm{g}$, and copolymer/DNA complexes were prepared in phosphate-buffered saline. (a) PA-PEI-SSI; (b) PA-PEI-SS2; (c) PA-PEI-SS3. (A) Retardation assay for PA-PEI-SS/DNA complexes in the presence of sodium heparin. From left: lane I(-), copolymer/DNA complexes without sodium heparin as control; lanes 2-7, copolymer/DNA complexes in various concentrations of sodium heparin $(200,400,600,800,1,000$, and I,200 $\mu \mathrm{g} / \mathrm{mL}$, respectively). (B) Retardation assay for PA-PEI-SS/DNA complexes at different N/P ratios. (C) DNase I protection assay. From left: lane I, naked DNA without DNase I; lane 2, naked DNA

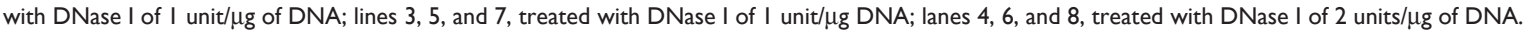

Abbreviations: N/P, copolymer/DNA charge; PA, Pluronic-diacrylate; PEl, polyethyleneimine; SS, disulfide; $U$, unit of DNase per $\mu g$ DNA.

degradation mechanisms. To evaluate these properties, the formation of the polyplexes was investigated using agarose gel retardation, TEM analysis, and measurements of particle size and zeta potential. As shown in Figure 4B, PA-PEI-SS1 started to form complexes at a low N/P ratio of approximately 3 , while a higher N/P ratio of 7 for PA-PEISS2 and PA-PEI-SS3 was needed for complete neutralization of DNA in the complexes formed. This capability for DNA condensation might be affected by the presence of a Pluronic shielding surface in the copolymer. For the control PEI-SS, DNA was neutralized at an N/P ratio of approximately 2.5 (data not shown). Increasing the Pluronic content in the copolymers decreases the positive charge on the polyplex surface, resulting in a higher N/P ratio required for complete neutralization of the DNA.

Naked DNA is easily digested by blood components. Sodium heparin, which was used to evaluate the stability of complexes in vivo with negative charges, was used to simulate molecules. At an N/P of 10, PA-PEI-SS1 and PA-PEI-SS3 were partially dissociated at a concentration of 1,000 or $1,200 \mu \mathrm{g} / \mathrm{mL}$. As shown in Figure 4A, the capacity of complexes to resist sodium heparin was very strong.

The interaction between negatively charged DNA and cationic polymer is known to strongly influence the efficiency of transfection efficiency. When the complex solution was incubated with DNase I, the polymer protected DNA from digestion by DNase I. Ultimately, intact DNA was released completely by the action of sodium heparin. Figure $4 \mathrm{C}$ shows that naked DNA was digested by DNase I at the concentration of $1 \mathrm{U}$ DNase I/ $\mu \mathrm{g}$ DNA, while, after complexing with the copolymer PA-PEI-SS copolymers, DNA was protected from DNase I in the presence of 1 or $2 \mathrm{U}$ DNase I/ $\mu \mathrm{g}$ DNA. Our DNase experiments suggest that DNA was protected by the vehicles of PA-PEI-SS copolymers instead of being degraded by DNase. Agarose gel electrophoresis results suggest that the dual-degradable copolymers are capable not only of forming complexes to resist sodium heparin, but also protecting the DNA from digestion by DNase I.

For efficient endocytosis and gene transfer, the complex needs to be small. ${ }^{34-36}$ The morphology of multiblock PAPEI-SS/DNA complexes in aqueous solution was examined by TEM at room temperature. The TEM image showed complex aggregates with a diameter of 150-250 nm (Figure 5). Interestingly, we also found a marked variation in aggregate morphology for the polyplexes in aqueous solution depending on the PEI-SS content in the copolymer chains. In general, with decreasing PEI-SS content, it is of benefit for polyplexes of PA-PEI-SS/DNA to assemble into aggregates. As shown in Figure 5, PA-PEI-SS2 and PA-PEI-SS3, which contain less PEI-SS content compared with PA-PEI-SS1, formed 

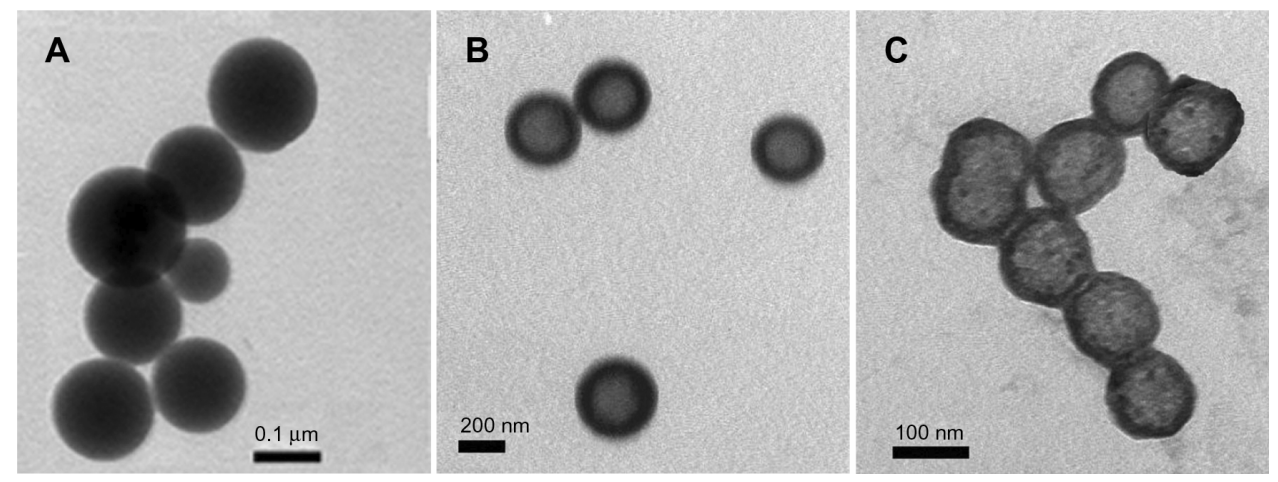

Figure 5 TEM microphotographs of polyplexes of pDNA with PA-PEI-SSI (A), PA-PEI-SS2 (B), and PA-PEI-SS3 (C) at an N/P ratio of 30 in water, formed and deposited on a copper grid.

Abbreviations: N/P, copolymer/DNA charge; PA, Pluronic-diacrylate; PEI, polyethyleneimine; SS, disulfide; TEM, transmission electron microscopy; pDNA, plasmid DNA.

complexes with DNA that assembled into a polyplexic structure different from the solid morphology of PA-PEISS1/DNA complexes. Since Pluronic is not charged, this assembly occurs via hydrophobic interactions between the poly(propylene oxide) chains of Pluronic and nonpolar sites in the polyplex. Thus, the Pluronic-PEI copolymers and pDNA could spontaneously associate into polyion complex aggregates, with a hydrophobic core formed by neutralized polyions and a hydrophilic shell formed by poly(ethylene oxide). The observed morphological structure is believed to be due mainly to changes in the degree of stretching of the blocks (poly[propylene oxide] and PEI segments/DNA polyplexes) in the core regions. PA-PEI-SS copolymers with a lower PEI-SS content showed weak pDNA condensation ability and this probably resulted in the observed morphology changes of PA-PEI-SS/pDNA polyplexes from solid to

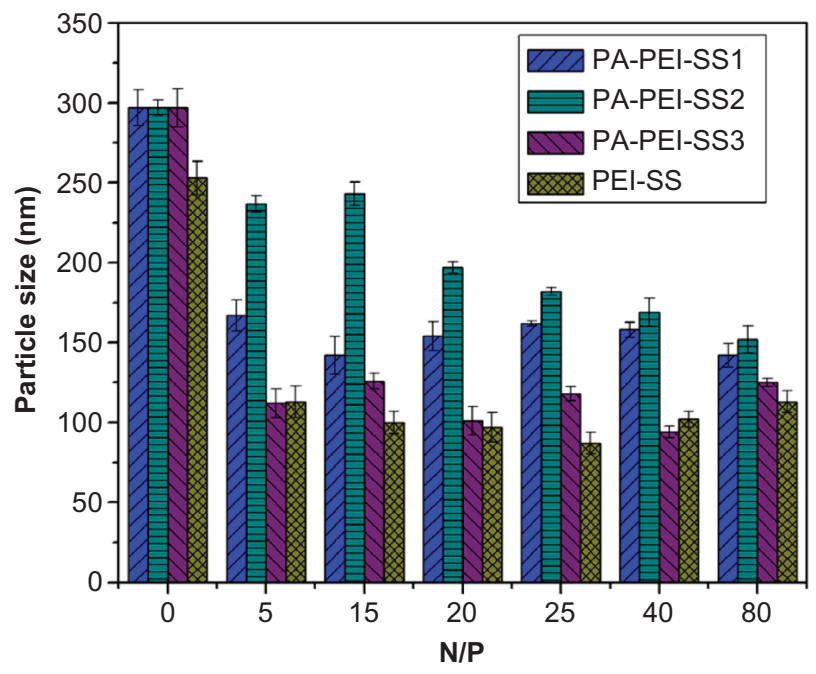

Figure 6 Particle size of copolymer/pDNA polyplexes at various N/P ratios. Notes: $\mathrm{n}=3$. Error bars represent standard deviations.

Abbreviations: N/P, copolymer/DNA charge; PA, Pluronic-diacrylate; PEI, polyethyleneimine; SS, disulfide. vesicular. The copolymer PA-PEI-SS1, with moderate PEI content, forms compact polyplexes that will, to some extent, facilitate gene transfection efficiency.

The particle sizes of the polyplexes were further determined as shown in Figure 6. We found that all tested copolymers were generally able to condense pDNA in polyplexes with particle sizes ranging from 100 to $300 \mathrm{~nm}$. This result is in accordance with TEM observations. The particle size varied with the N/P ratio. As the N/P ratio increased from 0 to 20 , the particle size for the polyplex was progressively reduced and reached a minimum value of $150 \mathrm{~nm}$ for the PA-PEI-SS1/pDNA complex. If the ratio of N/P was increased further, the particle size no longer decreased and remained nearly steady. At relatively high N/P ratios, net electrostatic repulsive forces between the complexes became stronger, resulting in the smaller sizes of these polyplexes. ${ }^{37}$

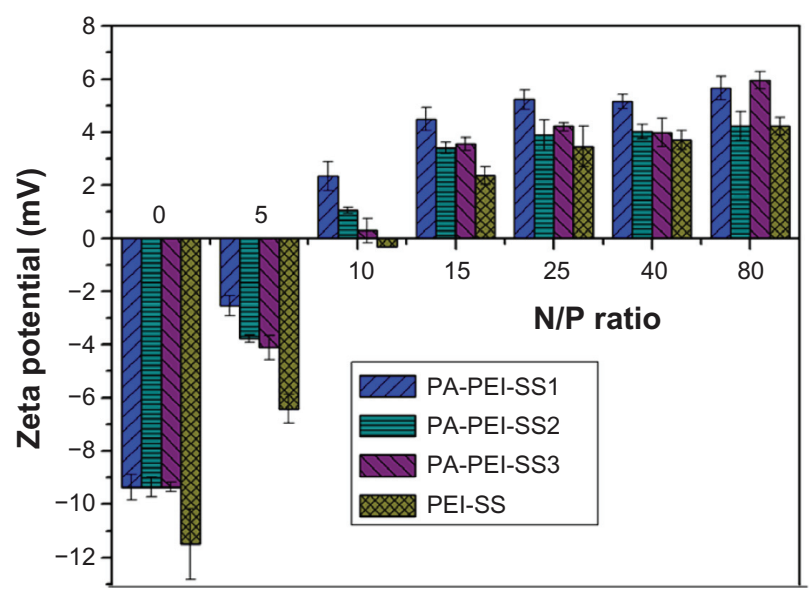

Figure 7 Surface charge of the copolymer/pDNA polyplexes in phosphate-buffered solution at various $\mathrm{N} / \mathrm{P}$ ratios.

Notes: $\mathrm{n}=3$. Error bars represent standard deviations.

Abbreviations: N/P, copolymer/DNA charge; PA, Pluronic-diacrylate; PEI, polyethyleneimine; SS, disulfide. 
Zeta potentials of polymer/DNA complexes are important for determining cellular uptake. ${ }^{38}$ As shown in Figure 7 , the zeta potential values showed a similar trend with changing $\mathrm{N} / \mathrm{P}$ ratios across the three PA-PEI-SS(1-3)/DNA complexes. The average potential of the three PA-PEI-SS copolymer/ pDNA complexes was approximately $8 \mathrm{mV}$. With increasing $\mathrm{N} / \mathrm{P}$ ratio, the zeta potentials gradually became positive. Compared with PA-PEI-SS1/pDNA, PA-PEI-SS2/pDNA and PAPEI-SS3/pDNA polyplexes with higher PEI-SS content had reduced zeta potential values for each N/P ratio, suggesting that reduced PEI content in the copolymer chains and the resulting lower positive charge may reduce the net surface charge of the PA-PEI-SS copolymers. In general, we believe that a relatively high surface charge on the polyplex enhances the interaction with the negatively charged cell membrane, and this positive potential also prevents the complexes from aggregation and guarantees the formation of small nanosize particles. However, the strong cationic nature of the polyplexes often leads to significant cytotoxicity and limits the clinical applications. Therefore, non-charged Pluronic-modified polycation copolymers, PA-PEI-SS, are expected to be safe and suitable candidates for effective transfection due to the charge-shielding properties of Pluronic-diacrylate.

\section{Dual-degradation of the copolymer}

The degradation of a gene vector is an important concern in the design of safe and efficient gene-therapy vehicles. Appropriate degradation of the polymer to smaller-molec-

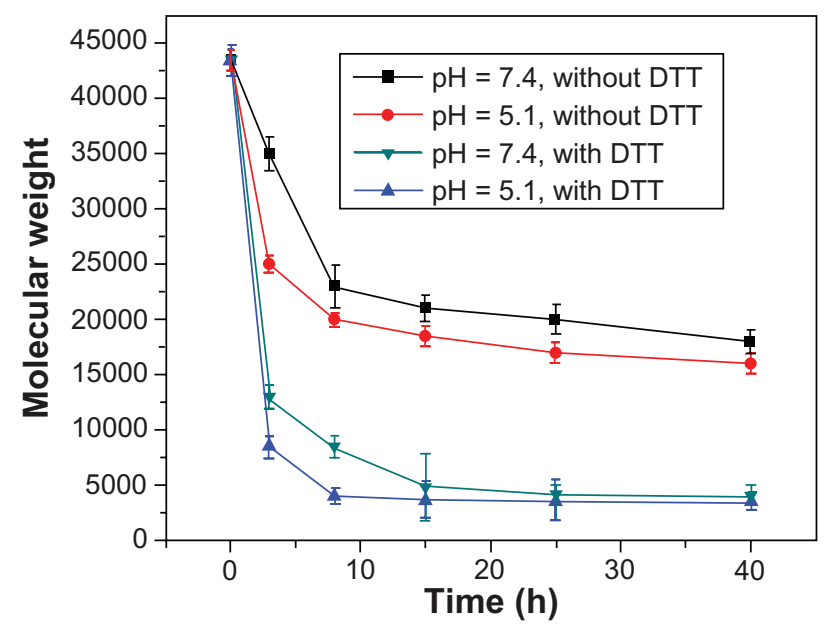

Figure 8 Dual-degradation of PA-PEI-SSI at $37^{\circ} \mathrm{C}$ at $\mathrm{pH} 5.1$ and $\mathrm{pH} 7.4$ in the presence and absence of DTT.

Note: Degradation is expressed as the molecular weight of the copolymer over time, based on GPC-MALLS data.

Abbreviations: DTT, dithiothreitol; GPC-MALLS, gel permeation chromatographymulti-angle laser light scattering; PA, Pluronic-diacrylate; PEI, polyethyleneimine; SS, disulfide. ular-weight molecules results in a reduction of cytotoxicity and facile elimination via the excretion pathway.

In the present study, degradation of PA-PEI-SS was monitored in the presence or absence of DTT at $37^{\circ} \mathrm{C}$, at buffered $\mathrm{pH}$ values of 5.1 and 7.4, to approximate the $\mathrm{pH}$ of the environments within the endosomal polyplexes and the cytoplasm, respectively. Figure 8 shows the degradation profiles of PA-PEI-SS1 as a function of time. In general, the copolymers showed initial rapid degradation, after which the molecular weight of the copolymers remained relatively constant. In the absence of DTT, the copolymer degraded hydrolytically in acetate buffer of $\mathrm{pH} 5.1$ or PBS of $\mathrm{pH} 7.4$ into smaller products with $M_{w}=20 \mathrm{kDa}$. In the presence of DTT, faster degradation (a half-life of less than 1.5 hours) of the copolymer into smaller products with a relative lower molecular weight $\left(M_{w}=5,000 \mathrm{Da}\right)$ was observed due to the rapid degradation of disulfide bonds in the PAPEI-SS chains in the reductive environment. Furthermore, the degradation of PA-PEI-SS was dependent on the $\mathrm{pH}$ of the incubation solution, with the copolymer degrading more rapidly at $\mathrm{pH} 5.1$ than at $\mathrm{pH} 7.4$ due to the catalysis occurring in the acidic environment. In the absence of DTT, PA-PEI-SS has a half-life of approximately 7 hours at $\mathrm{pH}$ 7.4; the molecular weight remained relatively constant at about $6.0 \mathrm{kDa}$ after 8 hours, which is very close to the $M_{w}$ of P123 (5.8 kDa). In contrast, the copolymer was completely degraded in less than 3 hours at $\mathrm{pH} 5.1$. These results suggest that PA-PEI-SS copolymers have good dual-degradable properties and would display rapid cleavage in the cytosol at a $\mathrm{pH}$ lower than 7.4.

\section{In vitro cytotoxicity}

Preventing cytotoxicity is a major challenge in the creation of nonviral vectors. The gene transfection efficiency of cationic copolymers is often limited by their cytotoxicity. Toxicity of the dual-degradable PA-PEI-SS copolymers was evaluated using 293T and BGC-823 cells; PEI-SS and PEI (25 kDa) were used as controls. The study was carried out for different polyplexes, with the concentration of the copolymer ranging from 0 to $0.5 \mathrm{mg} / \mathrm{mL}$. As shown in Figure 9A, PA-PEI-SS copolymers showed remarkably lower toxicity than PEI-SS and PEI $(2.5 \mathrm{kDa})$, and approximately $70 \%$ cell viability was maintained at concentrations up to $0.15 \mathrm{mg} / \mathrm{mL}$ in $293 \mathrm{~T}$ cells. On the contrary, at a concentration of $0.15 \mathrm{mg} / \mathrm{mL}$, cell viability decreased to $40 \%$ for PEI-SS and to almost $20 \%$ for PEI (2.5 kDa). Similar trends seen in the 293T cells were observed with increasing PA-PEI-SS copolymer concentrations in the BGC-823 cell line (Figure 9B). Compared with 
A

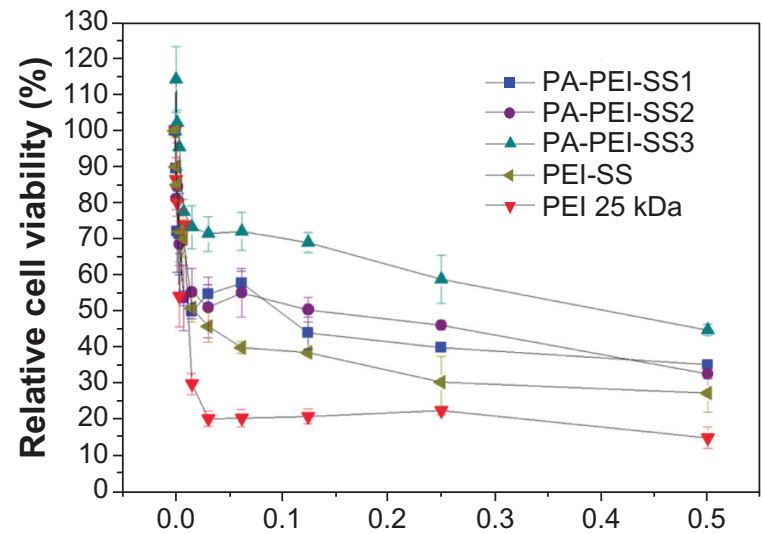

B Concentration of polymer $(\mathrm{mg} / \mathrm{mL})$

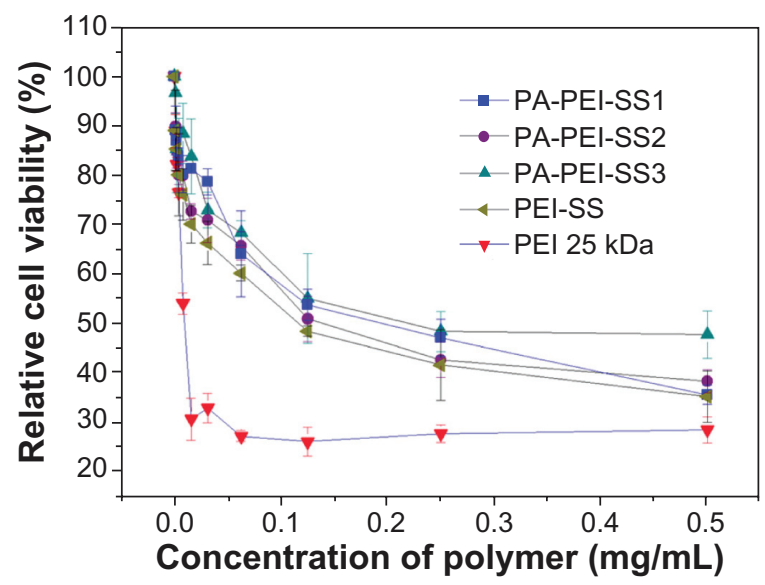

Figure 9 Cytotoxicity of PA-PEI-SS copolymers and PEI-SS and $25 \mathrm{kDa}$ PEI controls in (A) 293T and (B) BGC-823 cells after 48 hours' incubation.

Note: Data shown are mean \pm standard deviation $(n=3)$.

Abbreviation: PA, Pluronic-diacrylate; PEI, polyethyleneimine; SS, disulfide.

the copolymer cultured in $293 \mathrm{~T}$ cells, cell viability in the BGC-823 cell line was reduced slightly, but was still higher than that seen with controls. In the series of PA-PEI-SS copolymers, the highest cell viability was observed for PA-PEISS3, over the whole concentration range, in both cell lines, which is mainly related to the lower amine concentration in the copolymer chains of PA-PEI-SS3.

The half-maximal inhibitory concentrations $\left(\mathrm{IC}_{50}\right)$ of the polymers are summarized in Table 2. Compared with $25 \mathrm{kDa}$ PEI, the $\mathrm{IC}_{50}$ values of the PA-PEI-SS copolymers were much higher in both cell lines. For PA-PEI-SS3, the $\mathrm{IC}_{50}$ value was $343.66 \mu \mathrm{g} / \mathrm{mL}$ in $293 \mathrm{~T}$ cells, which is almost 300 times greater than the $\mathrm{IC}_{50}$ value for $25 \mathrm{kDa}$ PEI.

The low cytotoxicity of PA-PEI-SS is due to the introduction of Pluronic and the degradation of the copolymers. The poly(ethylene oxide) chain of Pluronic extends into the water and sterically hinders the complexes from approaching one another, shielding the positive charge of the complex surface and resulting in reduced cytotoxicity. The low cytotoxicity of dual-degradable PA-PEI-SS copolymers indicates that, after cellular binding and internalization, the copolymers can be intercellularly degraded, triggered by glutathione and the physiological environment, into products with relatively low toxicity. The concentrations of the copolymers employed in the in vitro gene transfection study were significantly lower than their $\mathrm{IC}_{50}$ values, and thus the toxicity data encouraged us to evaluate these bioreducible copolymers as candidates for gene delivery.

\section{In vitro transfection}

The transfection efficiency of the copolymers was generally dependent on cell line, copolymer molecular weight, and $\mathrm{N} / \mathrm{P}$ ratio. In the present study, pDNA encoding an EGFP-N1 (expressing green fluorescence) reporter gene was used to examine the transfection ability of PA-PEI-SS copolymers in two selected cell lines (293T and BGC-823 cells) at N/P ratios ranging from 10 to 40 . PEI-SS and branched $25 \mathrm{kDa}$ PEI were used as controls. The EGFP pDNA transfected cells incubated with the polymers showed many intracellular bright green fluorescent spots, as observed by fluorescence microscopy (Figure 10). Forty-eight hours after polyplex addition, three PA-PEI-SS copolymers displayed high EGFP transfection activity in both cell lines. For 293T cells, much stronger fluorescent densities were observed for the PAPEI-SS copolymers compared with PEI-SS and $25 \mathrm{kDa}$ PEI (Figure 10A-E). Similar results were obtained for BGC823 cells. As shown in Figure 10F-J, the copolymers also exhibited more transfection efficiency than the controls. The three PA-PEI-SS copolymers have different transfection activities, with a similar trend observed in both cell lines. PA-PEI-SS1 with higher PEI content showed the maximum fluorescent density in both cell lines. These results suggest that PA-PEI-SS1 displays specific transfection capability

Table $2 \mathrm{IC}_{50}$ values of PA-PEI-SS and PEI $25 \mathrm{kDa}$ in $293 \mathrm{~T}$ and BGC-823 cells

\begin{tabular}{lllllll}
\hline & Cell lines & PA-PEI-SSI & PA-PEI-SS2 & PA-PEI-SS3 & PEI-SS & PEI 25 kDa \\
\hline $\mathrm{IC}_{50}$ & $293 \mathrm{~T}$ & 99.8 & 131.54 & 343.66 & 22.03 & 11.284 \\
$(\mu \mathrm{g} / \mathrm{mL})$ & BGC-823 & 141.15 & 201.6 & 220.06 & 111.7 & 9.629 \\
\hline
\end{tabular}

Abbreviations: $I C_{50}$, half inhibitory concentration; PA, Pluronic-diacrylate; PEI, polyethyleneimine; SS, disulfide. 

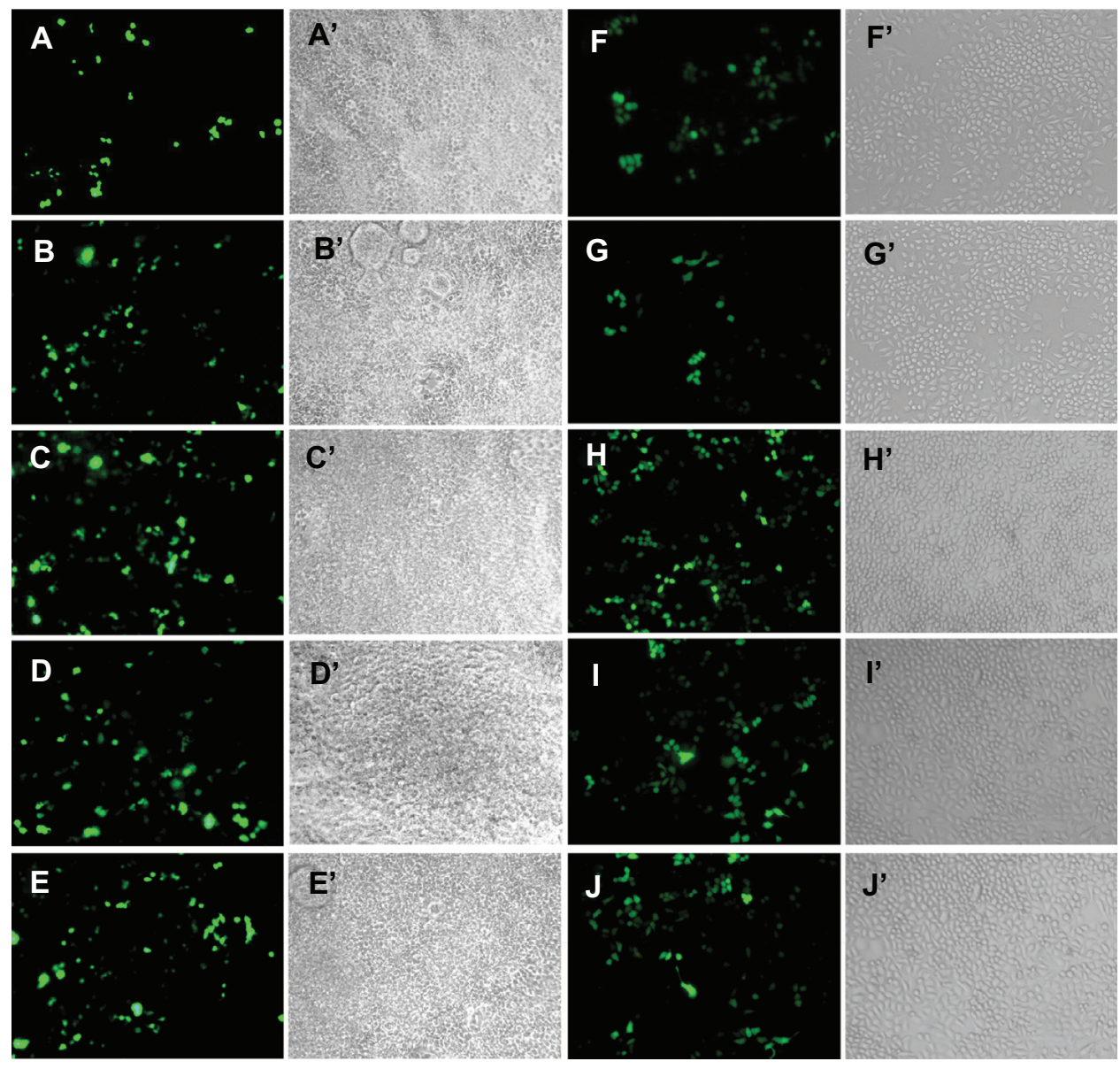

Figure 10 Green fluorescence images of 293T (A-E) and BGC-823 (F-J) cells transfected by complexes of pEGFP and PA-PEI-SS, or PEI-SS at N/P = 20 or 25 kDa PEI at N/P = 10. (A and F) 25 kDa PEl; (B and G) PEI-SS; (C and H) PA-PEI-SSI; (D and I) PA-PEI-SS2; (E and J) PA-PEI-SS3. The corresponding bright field images (A'-J') (A' and F') 25 kDa PEI; (B' and G') PEI-SS; (C' and H') PA-PEI-SSI; (D' and I') PA-PEI-SS2; (E' and J') PA-PEI-SS3.

Note: The micrographs were obtained at a magnification of I00X.

Abbreviations: N/P, copolymer/DNA charge; PA, Pluronic-diacrylate; PEI, polyethyleneimine; pEGFP, plasmid enhanced green fluorescent protein; SS, disulfide.

in $293 \mathrm{~T}$ and BGC-823 cell lines and could be a desirable gene carrier.

The percentage of EGFP-positive cells was further quantified by flow cytometry measurements. The PA-PEI-SS polyplexes showed significantly higher transfection efficiency than PEI-SS and $25 \mathrm{kDa}$ PEI in both cell lines at optimal N/P ratios (Figure 11). Maximum efficiency was observed for the PA-PEI-SS1 copolymer at an N/P ratio of 20, with $40 \%$ of 293 T cells positively expressing EGFP. This measure of efficiency was nearly three times higher than that observed with PEI-SS, and five times higher than with $25 \mathrm{kDa}$ PEI. In BGC-823 cells, the transfection efficiencies of PA-PEI-SS/ pDNA polyplex formulations were also higher than those of the controls. PA-PEI-SS1 transfected nearly $35 \%$ of the cell population at an N/P ratio of 20 , which was approximately four and five times higher than that observed for PEI-SS and $25 \mathrm{kDa}$ PEI, respectively. These results provide further proof that superior transfection efficiency is achieved with the bioreducible copolymer PA-PEI-SS, compared with the controls PEI-SS and $25 \mathrm{kDa}$ PEI, in both 293T and BGC823 cells.

The superior transfection observed in PA-PEI-SS copolymers compared with the controls, PEI-SS and $25 \mathrm{kDa}$ PEI, in cells can be explained as follows: (1) the intracellular cleavage of the copolymers and subsequent release of plasmid DNA can have a beneficial effect on transfection efficiency due to the improved access of plasmid DNA to the cellular transcription machinery. In this study, dual-degradable PA-PEI-SS copolymers were able to be completely degraded into nontoxic LMW PEI and Pluronic fragments in the presence of DTT and PBS (Figure 4), and, furthermore, the copolymers displayed more rapid degradation at a low $\mathrm{pH}$ level (pH 5.1 compared with $\mathrm{pH}$ 7.4), which may facilitate the release of DNA from complexes and escape of DNA from the endosome as well as improve the transfection. ${ }^{19}$ (2) The Pluronic content is considered to be necessary in 
A

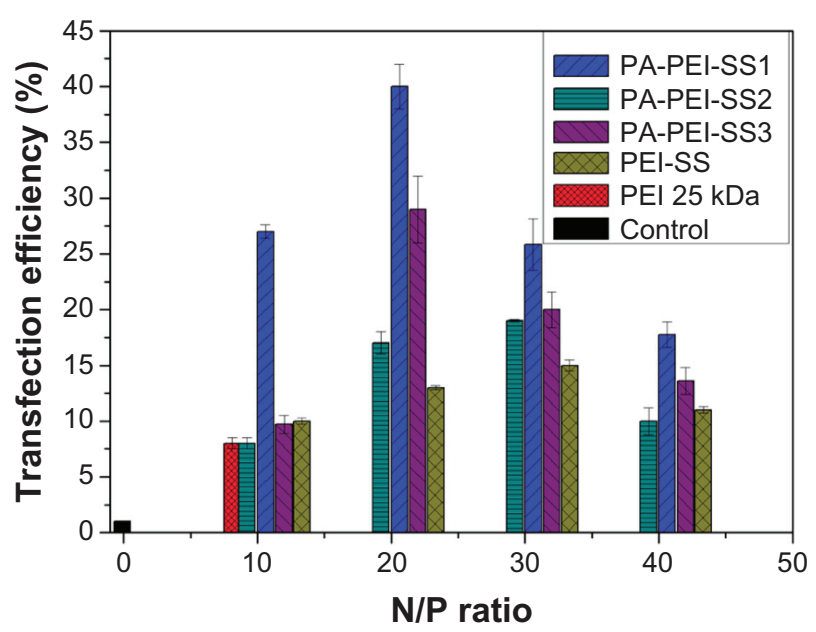

B

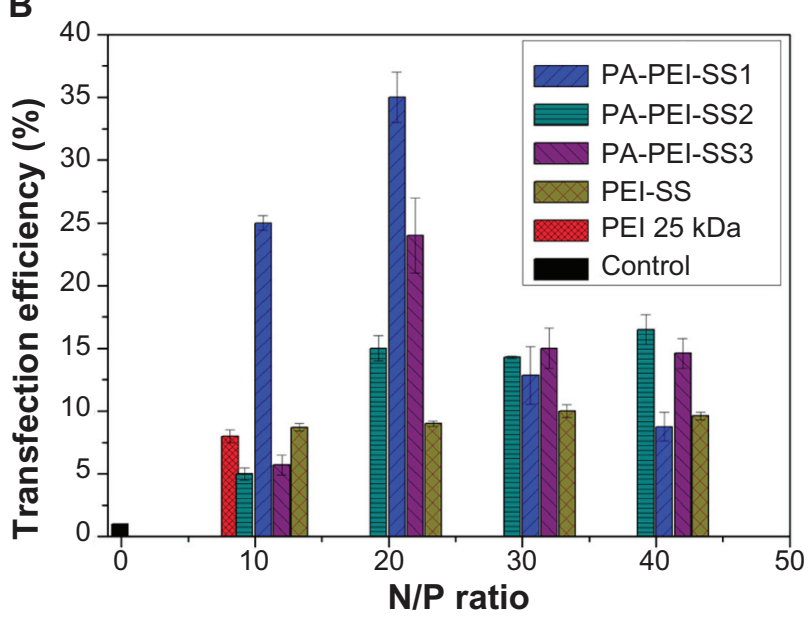

Figure II Flow cytometry measurements showing the percentage of EGFPexpressing cells at different ratios of N/P for PA-PEI-SS/DNA polyplexes and PEI-SS and $25 \mathrm{kDa}$ PEl controls.

Notes: (A) 293T cells; (B) BGC-823 cells. The cells were measured immediately after the photograph was taken. $n=3$. Error bars represent standard deviations. Abbreviations: EGFP, enhanced green fluorescent protein; N/P, copolymer/DNA charge; PA, Pluronic-diacrylate; PEI, polyethyleneimine; SS, disulfide.

the enhancement of efficiency due to its membrane properties of interacting with biological membranes and activating cell-signaling pathways. ${ }^{39,40} \mathrm{~A}$ higher content of hydrophilic Pluronic reduces the cell-penetrating effect, whereas a more hydrophobic PEI-SS will reduce cell viability. By adjusting the molar ratio of the PEI-SS with Pluronic in PA-PEI-SS with both ester bonds and disulfide bonds, it was possible to obtain considerable levels of gene transfection. PA-PEI-SS1 with suitable PEI contents produced the highest transfection ability at all N/P ratios (Figures 10 and 11). Also, PA-PEI-SS1 formed more compact polyplexes with a suitable particle size of about $150 \mathrm{~nm}$ (Figure 6), facilitating gene transfection efficiency, and thus indicating the necessary balance between the Pluronic and PEI-SS contents.

\section{Conclusion}

We successfully synthesized dual-degradable, polycation PA-PEI-SS copolymers, formed from cross-linking disulfide-containing PEI (800 Da) with PA via Michael addition. The dual degradability of the copolymers, based on reductive cleavage of disulfide bonds and ester hydrolysis, was demonstrated. PA-PEI-SS1 degraded hydrolytically in acetate buffer at $\mathrm{pH} 5.1$ or PBS media at $\mathrm{pH} 7.4$ into smaller products with $M_{w}=20 \mathrm{kDa}$, with the smaller product showing further rapid degradation to molecules with much lower molecular weights $\left(M_{w}=5 \mathrm{kDa}\right)$, in the presence of DTT, independent of the buffer $\mathrm{pH}$, whereas the rate of degradation in the absence of DTT was dependent on pH. PA-PEI-SS copolymers displayed strong pDNA condensation ability by forming positively charged nanoparticles and stability against DNase I digestion and sodium heparin. In vitro experiments indicated that the dual-degradable PA-PEI-SS copolymers displayed significantly higher transfection efficiency than that observed with PEI-SS and $25 \mathrm{kDa}$ PEI, in both BGC823 and $293 \mathrm{~T}$ cell lines, as well as much lower cytotoxicity. Transfection activity was influenced by the PEI-SS content, and the PA-PEI-SS1 copolymer showed the highest efficiency of the three copolymers.

\section{Acknowledgments}

We are grateful for the financial support of National Natural Science Foundation of China (21104029), Gansu Province Science Foundation for Youths (1107RJYA038), and Fundamental Research Funds for the Central Universities (lzujbky-2013-68). We thank Professor Youqing Shen for helpful discussion of the rational design for gene delivery vectors.

\section{Disclosure}

The authors report no conflicts of interest in this work.

\section{References}

1. Vile RG, Russell SJ, Lemoine NR. Cancer gene therapy: hard lessons and new courses. Gene Ther. 2000;7:2-8.

2. Ferrari S, Geddes DM, Alton EW. Barriers to and new approaches for gene therapy and gene delivery in cystic fibrosis. Adv Drug Deliv Rev. 2002;54:1373-1393.

3. Walsh CE. Gene therapy progress and prospects: gene therapy for the hemophilias. Gene Ther. 2003;10:999-1003.

4. Cristiano RJ. Viral and non-viral vectors for cancer gene therapy. Anticancer Res. 1998;18:3241-3245.

5. Pack DW, Hoffman AS, Pun S, Stayton PS. Design and development of polymers for gene delivery. Nat Rev Drug Discov. 2005;4:581-593.

6. Read ML, Logan A, Seymour LW. Barriers to gene delivery using synthetic vectors. Adv Genet. 2005;53:19-46.

7. Wong SY, Pelet JM, Putnam D. Polymer systems for gene delivery-past, present, and future. Prog Polym Sci. 2007;32:799-837. 
8. Godbey WT, Wu KK, Mikos AG. Poly(ethylenimine) and its role in gene delivery. J Control Release. 1999;60:149-160.

9. Nam HY, Nam K, Lee M, Kim SW, Bull DA. Dendrimer type bioreducible polymer for efficient gene delivery. $J$ Control Release. 2012;160:592-600.

10. Zhu K, Guo C, Lai H, et al. Novel hyperbranched polyamidoamine nanoparticles for transfecting skeletal myoblasts with vascular endothelial growth factor gene for cardiac repair. J Mater Sci Mater Med. 2011;22:2477-2485.

11. Boussif O, Zanta MA, Behr JP. Optimized galenics improve in vitro gene transfer with cationic molecules up to 1000 -fold. Gene Ther. 1996;3:1074-1080.

12. van Gaal EV, van Eijk R, Oosting RS, et al. How to screen non-viral gene delivery systems in vitro. J Control Release. 2011;154:218-232.

13. Abdallah B, Hassan A, Benoist C, Goula D, Behr JP, Demeneix BA A powerful nonviral vector for in vivo gene transfer into the adult mammalian brain: polyethylenimine. Hum Gene Ther. 1996;7:1947-1954.

14. Coll JL, Chollet P, Brambilla E, Desplanques D, Behr JP, Favrot M. In vivo delivery to tumors of DNA complexed with linear polyethylenimine. Hum Gene Ther. 1999;10:1659-1666.

15. Godbey WT, Wu KK, Mikos AG. Size matters: molecular weight affects the efficiency of poly(ethylenimine) as a gene delivery vehicle. J Biomed Mater Res. 1999;45:268-275.

16. Fischer D, Bieber T, Li Y, Elsässer HP, Kissel T. A novel non-viral vector for DNA delivery based on low molecular weight, branched polyethylenimine: effect of molecular weight on transfection efficiency and cytotoxicity. Pharm Res. 1999;16:1273-1279.

17. Tian H, Tang Z, Zhuang X, Chen X, Jing X. Biodegradable synthetic polymers: preparation, functionalization and biomedical application. Prog Polym Sci. 2012;37:237-280.

18. Wagner E, Kloeckner J. Gene delivery using polymer therapeutics. Advances in Polymer Science. 2006;192:135-173.

19. K C RB, Thapa B, Xu P. pH and redox dual responsive nanoparticle for nuclear targeted drug delivery. Mol Pharm. 2012;9:2719-2729.

20. Thomas M, Ge Q, Lu JJ, Chen J, Klibanov AM. Cross-linked small polyethylenimines: while still nontoxic, deliver DNA efficiently to mammalian cells in vitro and in vivo. Pharm Res. 2005;22:373-380.

21. Forrest ML, Koerber JT, Pack DW. A degradable polyethylenimine derivative with low toxicity for highly efficient gene delivery. Bioconjug Chem. 2003;14:934-940.

22. Wu J, Yamanouchi D, Liu B, Chu C. Biodegradable arginine-based poly(ether ester amide)s as a non-viral DNA delivery vector and their structure-function study. J Mater Chem. 2012;22:18983-18991.

23. Xia J, Tian H, Chen L, Lin L, Guo Z, Chen J. Oligoethylenimines grafted to PEGylated poly( $\beta$-amino ester)s for gene delivery. Biomacromolecules. 2011;12:1024-1031.

24. Xia J, Chen L, Tian H, Chen X, Maruyama A, Park TG. Synthesis of oligoethylenimine grafted net-poly(amino ester) and their application in gene delivery. J Control Release. 2011;152:176-177.

25. Anderson DG, Lynn DM, Langer R. Semi-automated synthesis and screening of a large library of degradable cationic polymers for gene delivery. Angew Chem Int Ed Engl. 2003;42:3153-3158.
26. Lai TC, Kataoka K, Kwon GS. Pluronic-based cationic block copolymer for forming pDNA polyplexes with enhanced cellular uptake and improved transfection efficiency. Biomaterials. 2011;32:4594-4603.

27. Bromberg L, Alakhov VU, Hatton TA. Self-assembling Pluronic ${ }^{\circledR}$ modified polycations in gene delivery. Curr Opin Colloid Interface Sci. 2006;11:217-223.

28. Ogris M, Brunner S, Schüller S, Kircheis R, Wagner E. PEGylated DNA/transferring-PEI complexes: reduced interaction with blood components, extended circulation in blood and potential for systemic gene delivery. Gene Ther. 1999;6:595-605.

29. Guo Q, Shi S, Wang X, et al. Synthesis of a novel biodegradable poly(ester amine) (PEAs) copolymer based on low-molecular-weight polyethyleneimine for gene delivery. Int J Pharm. 2009;379:82-89.

30. Kabanov AV, Lemieux P, Vinogradov S, Alakhov V. Pluronic block copolymers: novel functional molecules for gene therapy. Adv Drug Deliv Rev. 2002;54:223-233.

31. Liang W, Gong H, Yin D, Lu S, Fu Q. High-molecular-weight polyethyleneimine conjuncted pluronic for gene transfer agents. Chem Pharm Bull (Tokyo). 2011;59:1094-1101.

32. Liu C, Zhu Q, Wu W, et al. Degradable copolymer based on amphiphilic $\mathrm{N}$-octyl-N-quatenary chitosan and low-molecular weight polyethylenimine for gene delivery. Int J Nanomedicine. 2012;7:5339-5350.

33. DuY, Cai LL, Li J, et al. Receptor-mediated gene delivery by folic acidmodified stearic acid-grafted chitosan micelles. Int $J$ Nanomedicine. 2011;6:1559-1568.

34. Emilitri E, Ranucci E, Ferruti P. New poly(amidoamine)s containing disulfide linkages in their main chain. J Polym Sci A Polym Chem. 2005;43:1404-1416

35. Barnard A, Posocco P, Pricl S, et al. Degradable self-assembling dendrons for gene delivery: experimental and theoretical insights into the barriers to cellular uptake. JAm Chem Soc. 2011;133:20288-20300.

36. Alameh M, Dejesus D, Jean M, et al. Low molecular weight chitosan nanoparticulate system at low N:P ratio for nontoxic polynucleotide delivery. Int J Nanomedicine. 2012;7:1399-1414.

37. Park MR, Han KO, Han IK, et al. Degradable polyethyleniminealt-poly(ethylene glycol) copolymers as novel gene carriers. J Control Release. 2005;105:367-380.

38. Petersen H, Fechner PM, Martin AL, et al. Polyethylenimine-graftpoly(ethylene glycol) copolymers: Influence of copolymer block structure on DNA complexation and biological activities as gene delivery system. Bioconjug Chem. 2002;13:845-854.

39. Schulz M, Olubummo A, Binder WH. Beyond the lipid-bilayer: interaction of polymers and nanoparticles with membranes. Soft Matter. 2012;8:4849-4864.

40. Wang M, Lu P, Wu B, Tucker JD, Cloer C, Lu Q. High efficiency and low toxicity of polyethyleneimine modified Pluronics (PEI-Pluronic) as gene delivery carriers in cell culture and dystrophic $m d x$ mice. J Mater Chem. 2012;22:6038-6046.
International Journal of Nanomedicine

\section{Publish your work in this journal}

The International Journal of Nanomedicine is an international, peerreviewed journal focusing on the application of nanotechnology in diagnostics, therapeutics, and drug delivery systems throughout the biomedical field. This journal is indexed on PubMed Central, MedLine, CAS, SciSearch ${ }^{\circledR}$, Current Contents ${ }^{\circledR} /$ Clinical Medicine,

\section{Dovepress}

Journal Citation Reports/Science Edition, EMBase, Scopus and the Elsevier Bibliographic databases. The manuscript management system is completely online and includes a very quick and fair peer-review system, which is all easy to use. Visit http://www.dovepress.com/ testimonials.php to read real quotes from published authors. 